\title{
Modified Montmorillonite as Drug Delivery Agent for Enhancing Antibiotic Therapy
}

\author{
Luciana Sciascia $^{1, *(\mathbb{D})}$, Ilaria Calabrese ${ }^{2} \mathbb{D}$, Gennara Cavallaro ${ }^{3}$, Marcello Merli ${ }^{1} \mathbb{D}$, Cinzia Scialabba ${ }^{3} \mathbb{D}$ \\ and Maria Liria Turco Liveri ${ }^{2,+}$
}

1 Dipartimento di Scienze della Terra e del Mare (DiSTeM), University of Palermo, 90123 Palermo, Italy; marcello.merli@unipa.it

2 Dipartimento di Fisica e Chimica, University of Palermo, 90128 Palermo, Italy; calabrese.ilaria@gmail.com (I.C.); marialiria.turcoliveri@unipa.it (M.L.T.L.)

3 Dipartimento Scienze e Tecnologie Biologiche Chimiche e Farmaceutiche (STEBICEF), University of Palermo, 90123 Palermo, Italy; gennara.cavallaro@unipa.it (G.C.); cinzia.scialabba@unipa.it (C.S.)

* Correspondence: luciana.sciascia@unipa.it

+ This author has passed away.

Citation: Sciascia, L.; Calabrese, I.; Cavallaro, G.; Merli, M.; Scialabba, C.; Liveri, M.L.T. Modified Montmorillonite as Drug Delivery Agent for Enhancing Antibiotic Therapy. Minerals 2021, 11, 1315. https://doi.org/10.3390/min11121315

Academic Editor: Manuel Pozo Rodríguez

Received: 22 September 2021

Accepted: 23 November 2021

Published: 25 November 2021

Publisher's Note: MDPI stays neutral with regard to jurisdictional claims in published maps and institutional affiliations.

Copyright: (C) 2021 by the authors Licensee MDPI, Basel, Switzerland. This article is an open access article distributed under the terms and conditions of the Creative Commons Attribution (CC BY) license (https:// creativecommons.org/licenses/by/ $4.0 /)$

\begin{abstract}
The appealing properties of surfactant-intercalated Montmorillonites (Organo-montmorillonite, $\mathrm{OMt}$ ) were successfully investigated to propose an effective drug delivery system for metronidazole (MNE) antibiotic therapy. This represents a serious pharmaceutical concern due to the adverse drug reactions and the low targeting ability of MNE. The non-ionic surfactant Tween 20 was used to functionalize montmorillonite, thus accomplishing the two-fold objective of enhancing the stability of clay dispersion and better controlling drug uptake and release. The adsorption process was performed under different experimental conditions and investigated by constructing the adsorption isotherms through high-performance liquid chromatography (HPLC) measurements. Powder X-ray diffraction (XRD) measurements were performed to characterize the MNE/OMt compounds. The gathered results revealed that the uptake of the drug occurs preferentially in the clay interlayer, and it is governed by positive cooperative processes. The presence of surfactant drives the adsorption into clay interlayer and hampers the adsorption onto external lamella faces. The good performances of the prepared OMt in the controlled release of the MNE were proved by investigating the release profiles under physiological conditions, simulating oral drug administration. Cytotoxicity measurements demonstrated the biocompatibility of the complexes and evidenced that, under specific experimental conditions, nanodevices are more biocompatible than a free drug.
\end{abstract}

Keywords: montmorillonite; organoclay; metronidazole; surfactant; adsorption; release; drug delivery system

\section{Introduction}

In the few last decades, the use of surfactant-modified clay minerals (organoclays) in biomedical and pharmaceutical applications is gaining momentum, offering a promising strategy in solving cogent problems related to adverse effects and low targeting [1-7].

The functionalization with surfactants improves the already valuable performances of clay minerals [8-19] in terms of affinity towards organic drug molecules and stability of the formulation [20-26].

In this context, a great deal of interest [27-34] was focused on the montmorillonite (Mt), a layered aluminosilicate ( $1 \mathrm{~nm}$ in thickness) belonging to the smectite group, where sheets of octahedrally-coordinated $\mathrm{Al}$ atoms and tetrahedrally-coordinated $\mathrm{Si}$ atoms are stacked in a 2:1 ratio to form a T-O-T layer. The idealized structural formula for Mt is $(\mathrm{Na}, \mathrm{Ca})_{0.3}(\mathrm{Al}, \mathrm{Mg})_{2} \mathrm{Si}_{4} \mathrm{O}_{10}(\mathrm{OH})_{2} \cdot \mathrm{nH}_{2} \mathrm{O}$ [35]. Due to the extensive isomorphic substitutions, Mt clay is characterized by a high cation exchange capacity, which results in a high ability to adsorb cationic species. Furthermore, the presence of additional $\mathrm{pH}$-dependent 
charges arising on the broken edges of the clay, open routes to the possibility to properly modulate the adsorption features of the clay to selectively adsorb and release molecules of different nature. The above-mentioned structural features of Mt clay, together with its easy availability and biocompatibility, make this mineral clay particularly suitable for pharmacological applications.

Calabrese et al. [36] reported a study where the K10-montmorillonite was successfully exploited to formulate a drug delivery system for metronidazole (MNE), a powerful antibiotic mostly used for the treatment of intestinal amoebiasis [37,38]. The administration of MNE constitutes a serious pharmacological due to several adverse drug reactions and the low targeting ability related to both systemic and intravenous therapy [39-44]. To exert its efficient action against intestinal amoebiasis, MNE must be delivered directly in the colon [45-47]. However, the pharmacokinetic profile of the commercial oral formulation of the antibiotic indicates a very high absorption from the upper gastrointestinal tract, which reflects into severe unwanted systemic effects and a minimal amount reaching the colon for local action [48-53].

A comparison between the MNE/Mt hybrid materials with the commercial formulation of the MNE unveiled that the encapsulation of the drug onto Mt clay presents some important advantages, i.e., very low releasing rate of the MNE from the Mt formulation in the simulated gastric fluids $(\mathrm{pH}=1.0)$ and sustained release in the simulated intestinal fluids $(\mathrm{pH}=6.8)$.

In light of the effectiveness of the drug delivery system proposed by Calabrese et al. [36] and in response to the always growing demand for more performant formulations, the surfactant-functionalization of the Mt clay was here proposed as a strategy to (i) enhance the uptake toward the drug, (ii) obtain a better control the adsorption and release, and (iii) increase the dispersion stability in aqueous media.

The Polysorbates 20 (Tween20) was chosen as surfactant for the modification of clay surface, mainly due to its non-toxicity and biocompatibility, which allows the application in pharmacological formulations. In addition, previous studies [54] allowed us to assess the stabilization effect brought about by the adsorption of the surfactant on the Mt dispersions. The stability of the clay mineral dispersion is a crucial parameter for applications in pharmaceutical formulations since it strongly improves the degree of repeatability of the drug adsorption process and the bioavailability of the drug.

The release profiles of MNE from the organo-montmorillonite (OMt) in both simulated gastric and intestinal fluids $\mathrm{pH}$ were obtained. Preliminary to the releasing study, the systems were characterized from a physico-chemical point of view. Equilibrium studies were carried out to elucidate the adsorption mechanism of the MNE into the OMt and establish the nature of the interactions involved in the hybrid MNE/OMt formation. Moreover, the sites of interactions of the clay mineral surface were proposed based on the XRD results. To have a complete picture of the applicability of the new tailor-made systems, the cytocompatibility of nanodevices' constituents, i.e., Tween20, Mt, OMt, and that of the drug-loaded organo-clay was evaluated through MTS assay.

\section{Materials and Methods}

\subsection{Materials}

K10-montmorillonite (K10), polyoxyethylene sorbitan monolaurate (Tween 20), hydrochloric acid $(\mathrm{HCl})$, and sodium hydroxide $(\mathrm{NaOH})$ standard solutions were purchased from Sigma Aldrich (St. Louis, MO, USA).

$\mathrm{K} 10$ is an acid-treated montmorillonite with a partially destroyed structure, extensively exploited as sorbent in biomedical, industrial, and environmental applications [55-62].

It possesses a BET surface area of $220 \mathrm{~m}^{2} / \mathrm{g}$, CEC of $119 \mathrm{meq} / 100 \mathrm{~g}$, and the following structural formula [63]:

$\left(\mathrm{K}_{0.25} \mathrm{Na}_{0.118} \mathrm{Ca}_{0.022}\right)\left(\mathrm{Al}_{1.06} \mathrm{Fe}_{0.206} \mathrm{Mg}_{0.166}\right)\left(\mathrm{Si}_{7.39} \mathrm{Al}_{0.61}\right) \mathrm{O}_{20}(\mathrm{OH})_{4}$.

The Zeta potential of $\mathrm{K} 10$ is negative at all the $\mathrm{pH}$ values [64], therefore the clay does not present an isoelectric point and the surface is always negatively charged. 
Metronidazole (MNE), 1-hydroxyethyl-2-methyl-5-nitroimidazole was provided from Fluka.

SpectraPor dialysis tubing, with a nominal molecular weight cut-off (MWCO) of 1000 Da, was purchased from Spectrum Laboratories, Inc. (Palazzo Pignano, Italy). Hard gelatine capsules were purchased from Sigma Aldrich.

All materials were used as received.

Stock solutions of all chemicals used were prepared by weight before use. Deionized water from reverse osmosis (Elga, model Option 3), having resistivity higher than $1 \mathrm{M} \Omega \mathrm{cm}$, was used to prepare all solutions.

\subsection{Organo-Montmorillonite Preparation}

The OMt samples were prepared at $\mathrm{pH}=2.5$, according to the procedure previously described [21].

TGA measurements previously performed [21] indicate that the Tween20 weight fraction $\left(\chi_{s}\right)$ in the organo-clays, obtained by using the rule of mixtures [65], is $0.23 \pm 0.01 \mathrm{wt} \%$.

\subsection{MNE/OMt Preparation}

The metronidazole was adsorbed onto the OMt at three different $\mathrm{pH}(\mathrm{pH} 0.2, \mathrm{pH} 2.5$, $\mathrm{pH} 5.0)$, by keeping constant the concentration of OMt $\left(30 \mathrm{mg} \cdot \mathrm{mL}^{-1}\right)$ and varying the concentration of metronidazole in the range $0.3-8.0 \mathrm{mg} \cdot \mathrm{mL}^{-1}$ at $25.0{ }^{\circ} \mathrm{C}$.

These experimental conditions were selected because the $\mathrm{pKa}(2.5)$ of the metronidazole ensure, for $\mathrm{pH}<\mathrm{pKa}$ and $\mathrm{pH}>\mathrm{pKa}$, the prevalent presence in aqueous solutions of the cationic species and neutral species, respectively, while at $\mathrm{pH}=\mathrm{pKa}$ both the cationic and neutral species represent the absorbable molecules.

Aqueous $\mathrm{HCl}$ solutions at the desired $\mathrm{pH}(0.2,2.5$, and 5.0) were prepared by proper dilution of the standard solutions.

MNE aqueous stock solutions were prepared by weighting the antibiotic and dissolving it with the aqueous $\mathrm{HCl}$ solution at the required $\mathrm{pH}$.

Clay aqueous suspensions were prepared by crushing the OMt in an agate mortar and then mixing the requested amount of powder with the aqueous $\mathrm{HCl}$ solution prepared as described above. The obtained dispersions were stirred for about $2 \mathrm{~h}$ before use.

In both cases, the $\mathrm{pH}$ of the aqueous solutions/dispersions were measured and, when necessary, it was adjusted to the proper value by adding microvolumes of $\mathrm{HCl}$ or $\mathrm{NaOH}$ standard solutions.

The MNE/OMt hybrids, at a given $\mathrm{pH}$, were obtained by following the procedure previously described [36]. Briefly, appropriate aliquots of the drug aqueous solution were added to the aqueous OMt dispersions. The obtained dispersions were stirred at $100 \mathrm{rpm}$ for $5 \mathrm{~h}$, a stirring time that ensures that the adsorption processes reach the equilibrium, as demonstrated by preliminary kinetic experiments, and then, centrifuged for $10 \mathrm{~min}$ at $8000 \mathrm{rpm}$ through a Centra MP4R IEC centrifuge (Thermo Fisher Scientific, Waltham, MA, USA).

Then, the solid was either first frozen and after lyophilized by using a Freeze Dry System Labconco or air-dried for 2 days and then crushed in an agate mortar. The former treatment allowed us to prepare the samples to be used for both the release and cytotoxicity tests while the latter one was applied for obtaining the samples to be used for XRD characterization.

\subsection{Chromatographic Measurements}

The concentration of metronidazole in aqueous solutions was evaluated via highperformance liquid chromatography (HPLC) using Liquid Chromatography (1100 Series, Agilent Technologies, Deutschland $\mathrm{GmbH}$, Ehningen, Germany) equipped with a UV-vis detector model Kontron 432. For the chromatographic separation, an inverse phase column Gemini C18 $110 \AA$ from Phenomenex was used as stationary phase, and a mobile phase composed by a mixture of acetonitrile and a $5-\mathrm{mmol} \cdot \mathrm{L}^{-1} \mathrm{KH}_{2} \mathrm{PO}_{4}(\mathrm{pH}=3.0)$ aqueous 
solution in the ratio $8 / 92(\mathrm{v} / \mathrm{v})$, the applied flow velocity was $1 \mathrm{~mL} \cdot \mathrm{min}^{-1}$. Samples were monitored at $313 \mathrm{~nm}$ [66]. The validity of the Lambert-Beer law was verified over a wide range of drug concentrations $\left(0.005-1.1 \mathrm{mg} \cdot \mathrm{mL}^{-1}\right)$.

HPLC calibration curve is reported in the Supplementary Material (Figure S1).

\subsection{Adsorption Isotherms}

The adsorption process of MNE onto the biocompatible organo-clays was studied over a wide range of concentration of antibiotic by keeping constant the concentration of the organo-clay at fixed $\mathrm{pH}$ values $(\mathrm{pH}=0.2,2.5,5.0)$, according to the procedure described in the above section (sample preparation) The adsorption isotherms were collected by determining the metronidazole equilibrium concentration (Ce) in the supernatant, then, the amount of adsorbed drug (Cs) onto the OMt was estimated from the difference between the initial antibiotic concentration and Ce.

The MNE equilibrium concentration was estimated through HPLC as reported above.

Experiments were carried out in triplicate and the results were reported as average values.

\subsection{Kinetic of MNE Release}

The MNE/OMt samples containing the highest amount of loaded drug were selected for studying the in vitro MNE kinetic release, at $37.0^{\circ} \mathrm{C}$, in simulated gastric fluid (SGF, $\mathrm{pH} 1$ ) and simulated intestinal fluid (SIF, $\mathrm{pH} 6.8$ ), to reproduce the oral drug administration under physiological $\mathrm{pH}$ conditions $[67,68]$. The MNE release measurements from the MNE/OMt hybrids were carried out in two steps. In the first step, $500 \mathrm{mg}$ of the sample were encased in a hard gelatine capsule that was placed inside a dialysis membrane to which were then added $5 \mathrm{~mL}$ of $\mathrm{HCl} 0.1 \mathrm{~mol} \cdot \mathrm{L}^{-1}$ (SGF). The membrane containing the capsule was immersed in a beaker filled with $100 \mathrm{~mL} \mathrm{SGF}$ and incubated at $37^{\circ} \mathrm{C}$ under continuous stirring (100 rpm) in an Orbital placed (Thermo Fisher Scientific, Waltham, MA, USA) for $2 \mathrm{~h}$ at $37.0^{\circ} \mathrm{C}$. In the second step, after $2 \mathrm{~h}$, the membrane was taken away and put in a cylinder glass containing $100 \mathrm{~mL}$ of phosphate buffer at $\mathrm{pH} 6.8$ (SIF), and the system was maintained at $37.0^{\circ} \mathrm{C}$ in the Orbital Shaker for $6 \mathrm{~h}$. In both steps at scheduled time intervals, $1 \mathrm{~mL}$ of the release medium was withdrawn and analyzed by HPLC. The release medium volume was kept constant by adding $1 \mathrm{~mL}$ of fresh solutions of either $0.1 \mathrm{~mol} \cdot \mathrm{L}^{-1}$ $\mathrm{HCl}$ or phosphate buffer at $\mathrm{pH} 6.8$ to replace the collected one. The $\mathrm{pH}$ inside the dialysis membrane and in the release medium was checked at the end of the experiments.

The reported results are averaged over three experiments.

\subsection{XRD Characterization}

Powder X-ray diffractometry measurements were performed for the MNE/OMt hybrids, prepared in the whole $\mathrm{pH}$ range and, for the sake of comparison, for the clay in the absence of additives. The samples were mounted on aluminum plates and the XRD patterns were acquired at room temperature with a Philips X-ray diffractometer (PW 1729, Netherland) using Ni-filtered $\mathrm{Cu} \mathrm{K} \alpha$ radiation with $\lambda 1.5406 \AA$, in the range of scattering angles $2 \theta=4-25^{\circ}$ at the rate of $0.01^{\circ} \mathrm{s}^{-1}$.

\subsection{Cell Viability Assay on Human Colon Cancer (HCT116) Cells}

Cell viability was assessed by the MTS assay on human colon cancer (HCT116) cell lines, (purchased from Istituto Zooprofilattico Sperimentale della Lombardia e dell' Emilia Romagna, Italy) a model of colorectal cancer cells $[69,70]$ using a commercially available kit (Cell Titer 96 Aqueous One Solution Cell Proliferation assay, Promega).

The MTS assay is based on the ability of mitochondrial dehydrogenases in viable cells to convert the MTS salt into a colored formazan product, which can be quantitatively detected by spectrophotometry at a $\lambda \max$ of $490 \mathrm{~nm}$. The obtained absorbance is directly proportional to the number of living cells in the culture.

HCT116 cells $\left(2.5 \times 10^{4}\right.$ cells/well $)$ were seeded in 96 well plates and grown in Dulbecco's Minimum Essential Medium (DMEM) with 10\% FBS (foetal bovine serum) 
and $1 \%$ of penicillin/streptomycin $(10,000 \mathrm{U} / \mathrm{mL}$ penicillin and $10 \mathrm{mg} / \mathrm{mL}$ streptomycin) at $37^{\circ} \mathrm{C}$ in $5 \% \mathrm{CO}_{2}$ humidified atmosphere. After $24 \mathrm{~h}$, the medium was replaced with $200 \mu \mathrm{L}$ of fresh culture medium containing the free drug and the drug loaded onto $\mathrm{Mt}$ and OMt. The concentration per well of MNE was varied in the range $0.75-15 \mu \mathrm{g} \cdot \mathrm{mL}^{-1}$. After 4 and $24 \mathrm{~h}$, DMEM was replaced with $100 \mu \mathrm{L}$ of fresh medium, and $20 \mu \mathrm{L}$ of a MTS solution was added to each well. Plates were incubated for an additional $2 \mathrm{~h}$ at $37^{\circ} \mathrm{C}$. Then, the absorbance at $490 \mathrm{~nm}$ was measured using a microplate reader (Multiskan, Thermo, Heysham, UK). A pure cell medium was used as a negative control.

The same experiment was performed incubating HCT116 cells with Tween20 (0.011-0.22 $\left.\mathrm{mg} \cdot \mathrm{mL}^{-1}\right)$, OMt $\left(0.05-1 \mathrm{mg} \cdot \mathrm{mL}^{-1}\right)$, and $\mathrm{K} 10\left(0.02-1 \mathrm{mg} \cdot \mathrm{mL}^{-1}\right)$.

Results were expressed as percentage reduction of the control cells. All culture experiments were performed in triplicates.

\section{Results}

\subsection{Adsorption Isotherms}

The amount of antibiotic adsorbed per gram of organo-clay (Cs, mmol. $\mathrm{g}^{-1}$ ) was evaluated from the absorbance values of the equilibrium process and plotted as a function of the equilibrium concentration of metronidazole in the solution $\left(\mathrm{Ce}, \mathrm{mol} \cdot \mathrm{L}^{-1}\right.$ ) (Figure 1).

It can be observed, that, analogously to the MNE uptake onto non-functionalized Mt [36], the loading capacity is a function of $\mathrm{pH}$, and, specifically, it decreases on an increasing $\mathrm{pH}$.

Different models, currently applied in the analysis of adsorption data (i.e., Langmuir, Freundlich, Dual-mode Langmuir, Dual-mode Freundlich, Hill models) were applied. The discrimination between the models was performed through some statistical criteria, as reported in Table 1. The reader can refer to Merli et al. [71] for a detailed description of these statistics.

Table 1. Selected figures of merit for the models applied to the experimental adsorption isotherms.

\begin{tabular}{|c|c|c|c|c|}
\hline Adsorption Isotherm Model & Figures of Merit & pH 0.2 & pH 2.5 & pH 5.0 \\
\hline \multirow{4}{*}{$\begin{array}{c}\text { Langmuir } \\
C_{S}=\frac{q^{m} \cdot K_{L} \cdot C_{e}}{1+K_{L} \cdot C_{e}}\end{array}$} & $\mathrm{R}^{2}$ & 0.98 & 0.98 & 0.94 \\
\hline & $x^{2}$ & $6.1 \times 10^{-6}$ & $1.4 \times 10^{-5}$ & $1.4 \times 10^{-5}$ \\
\hline & $\hat{\mathrm{ESS}}$ & $2.4 \times 10^{-5}$ & $6.2 \times 10^{-5}$ & $5.7 \times 10^{-5}$ \\
\hline & ANOVA F value & 866 & 200 & 94 \\
\hline \multirow{4}{*}{$\begin{array}{l}\text { Freundlich } \\
C_{S}=K_{F} \cdot C_{e}^{\frac{1}{n_{F}}}\end{array}$} & $\mathrm{R}^{2}$ & 0.94 & 0.98 & 0.94 \\
\hline & $\chi^{2}$ & $3.0 \times 10^{-5}$ & $7.9 \times 10^{-6}$ & $1.6 \times 10^{-5}$ \\
\hline & ESS & $1.2 \times 10^{-4}$ & $3.2 \times 10^{-5}$ & $6.3 \times 10^{-5}$ \\
\hline & ANOVA F value & 174 & 394 & 84 \\
\hline \multirow{4}{*}{$\begin{array}{l}\text { Dual mode } \\
\text { Langmuir } \\
\frac{q^{m} \cdot K_{L} \cdot C_{e}}{1+K_{L} \cdot C_{e}}+K^{\prime} C e\end{array}$} & $\mathrm{R}^{2}$ & 0.98 & 0.97 & 0.94 \\
\hline & $x^{2}$ & $6.8 \times 10^{-6}$ & $2.1 \times 10^{-5}$ & $1.8 \times 10^{-5}$ \\
\hline & ESS & $2.0 \times 10^{-5}$ & $6.2 \times 10^{-5}$ & $5.5 \times 10^{-5}$ \\
\hline & ANOVA F value & 522 & 100 & 49 \\
\hline \multirow{4}{*}{$\begin{array}{c}\text { Dual mode } \\
\text { Freundlich } \\
=K_{F} \cdot C_{e}^{\frac{1}{n}}+K^{\prime} C e\end{array}$} & $\mathrm{R}^{2}$ & 0.98 & 0.99 & 0.94 \\
\hline & $x^{2}$ & $1.1 \times 10^{-5}$ & $9.7 \times 10^{-6}$ & $2.1 \times 10^{-5}$ \\
\hline & ESS & $3.1 \times 10^{-5}$ & $2.9 \times 10^{-5}$ & $6.3 \times 10^{-5}$ \\
\hline & ANOVA F value & 335 & 214 & 42 \\
\hline \multirow{4}{*}{$C_{S}=\frac{\underset{q^{m} \cdot C_{e}^{n_{H}}}{\text { Hill }}}{K_{H}+C_{e}^{n_{H}}}$} & $R^{2}$ & 0.99 & 0.99 & 0.99 \\
\hline & $x^{2}$ & $3.9 \times 10^{-6}$ & $1.5 \times 10^{-6}$ & $1.7 \times 10^{-6}$ \\
\hline & ESS & $1.2 \times 10^{-5}$ & $5.8 \times 10^{-6}$ & $5.2 \times 10^{-6}$ \\
\hline & ANOVA F value & 903 & 1217 & 519 \\
\hline
\end{tabular}

Note: $C_{S}=$ amount of adsorbed drug, $C_{e}=$ drug equilibrium concentration, $q^{m}=$ maximum adsorption capacity $K_{L}=$ Langmuir adsorption constant, $K_{F}=$ Freundlich adsorption constant, $\mathrm{n}_{\mathrm{F}}=$ empirical constant, $K^{\prime}=$ Partition coefficient, $K_{H}=$ Hill adsorption constant, $\mathrm{n}_{\mathrm{H}}=$ Hill cooperativity coefficient. 

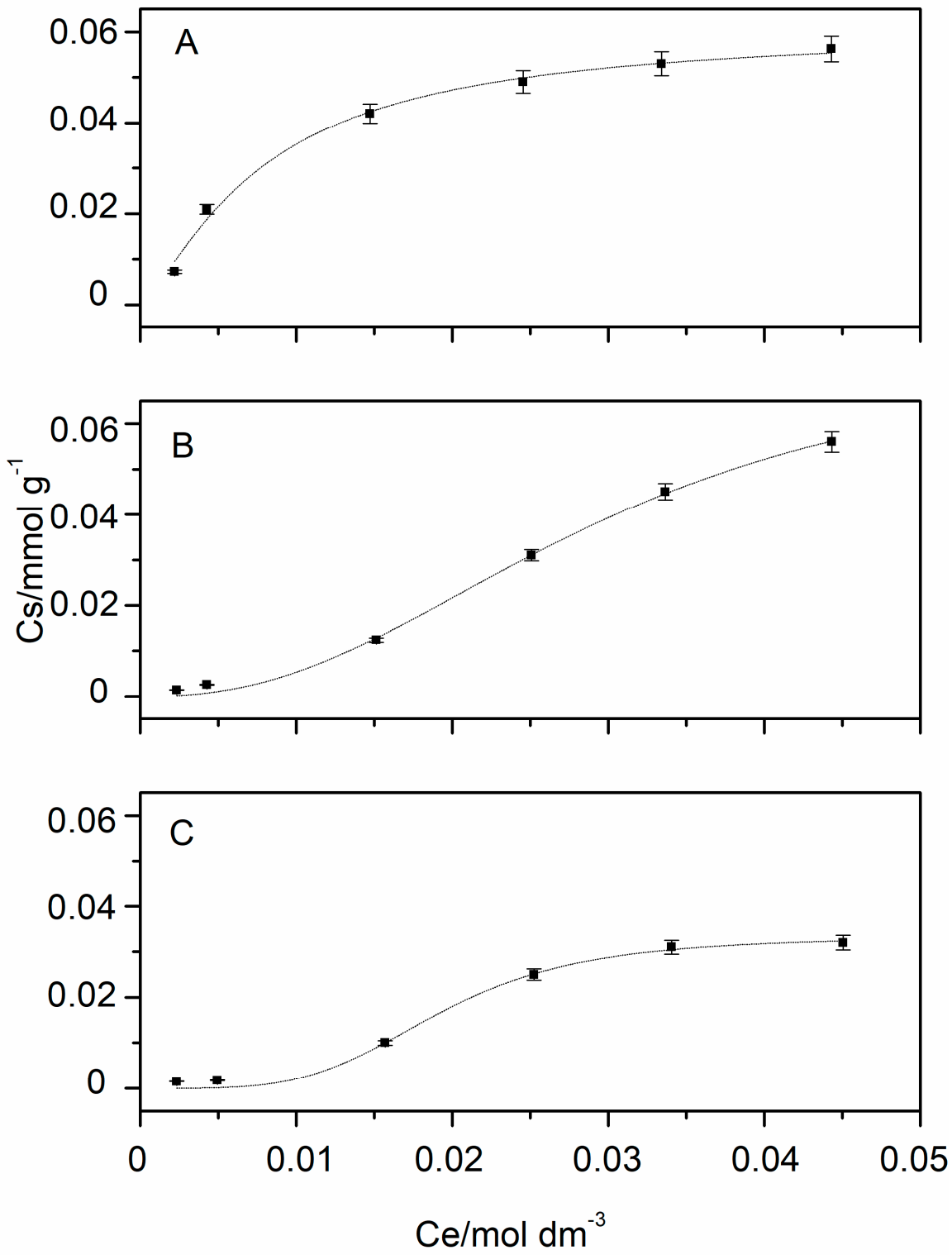

Figure 1. Adsorption isotherms of metronidazole onto organo-montmorillonites at $\mathrm{pH}=0.2$ (A), $\mathrm{pH}=2.5(\mathbf{B}), \mathrm{pH}=5(\mathbf{C}) . \mathrm{T}=25.0^{\circ} \mathrm{C}$. Symbols denote experimental points; line corresponds to the fit by Hill model. Vertical bars represent the SD, results are shown as mean \pm S.D.; $n=3$.

It was found that the model that better reproduces experimental data is the Hill model, which assumes that adsorption is a cooperative phenomenon, where the ligand binding ability at one site on the substrate, may influence different binding sites on the same substrate [72]. Sorption parameters are reported in Table 2.

Table 2. Sorption parameters of the Hill model for the adsorption isotherms of metronidazole onto organo-montmorillonite.

\begin{tabular}{cccc}
\hline $\mathbf{p H}$ & $\mathbf{0 . 2}$ & $\mathbf{2 . 5}$ & $\mathbf{5 . 0}$ \\
\hline$q^{m} / \mathrm{mmol} \cdot \mathrm{g}^{-1}$ & $0.061 \pm 0.004$ & $0.08 \pm 0.01$ & $0.033 \pm 0.002$ \\
$K_{H} / \mathrm{L} \cdot \mathrm{mol}^{-1}$ & $130 \pm 20$ & $33 \pm 4$ & $52 \pm 3$ \\
$n$ & $1.3 \pm 0.2$ & $2.4 \pm 0.3$ & $4.1 \pm 0.7$ \\
$R^{2}$ & 0.98985 & 0.99671 & 0.99138 \\
\hline
\end{tabular}


Comparison between the sorption parameters (Table 1) indicated that the maximum adsorption capacity $\left(q^{m}\right)$ is higher at $\mathrm{pH}=2.5$.

\subsection{Analysis of XRD Data}

The adsorption site of the drug into the OMt was investigated by means of powder $X$-ray diffraction measurements. X-ray diffraction patterns of the organoclays loaded with the metronidazole at the three different $\mathrm{pH}$ and, for comparison, those of the organoclays in the absence of drug, were registered (Figure 2).

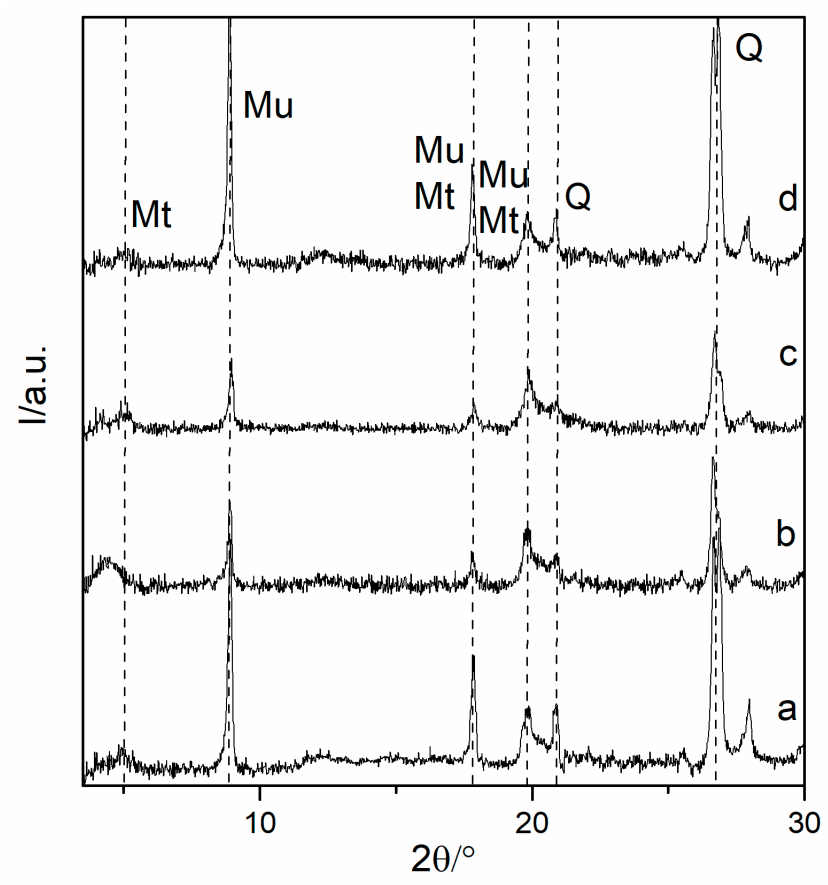

Figure 2. XRD patterns of organo-montmorillonite (a) and metronidazole/organo-montmorillonite complexes prepared at pH 0.2 (b), pH 2.5 (c), and pH 5.0 (d). Montmorillonite (Mt), muscovite (Mu), and quartz (Q).

According to the literature $[60,73]$, the XRD pattern of $\mathrm{K} 10$ is characterized by the presence of a weak and broad reflection d001 at $2 \theta \sim 5^{\circ}(\mathrm{d} 001 \sim 17.5 \AA)$, related to montmorillonite clay minerals, and a sharp peak at $2 \theta \sim 8.9^{\circ}(\mathrm{d} 001=9.9 \AA)$, which is attributed to clay mineral of the mica group (muscovite). Reflections corresponding to quartz are also present in the pattern at $2 \theta=26.5^{\circ}(\mathrm{d} 101=3.4 \AA)$ and $2 \theta=20.9^{\circ}(\mathrm{d} 112=4.2 \AA)$.

The clay structure is maintained during the adsorption process of the drug at any investigated $\mathrm{pH}$ value. However small changes in the low angle region can be recognized, thus assessing the successful intercalation of the drug in the Mt clay interlayer. A better view of this effect is provided in Figure 3 where the superimposition of the smoothed XRD patterns in this region is reported.

Regardless of the loading $\mathrm{pH}$ of metronidazole, the interaction between the drug and organoclay gives rise to an additional reflection at $2 \theta=4.15^{\circ}(\mathrm{d}=21.3 \AA)$, whose intensity decreases on increasing the loading $\mathrm{pH}$, which proves the successful intercalation of the drug in the clay interlayer, following the same trend of the adsorption capacity obtained from the adsorption isotherms.

The characteristic peak of the Mt, corresponding to a d spacing of $17.7 \AA$ remains almost unchanged for the hybrids prepared at $\mathrm{pH} 2.5$ and 5.0, thus suggesting a partial filling of Mt basal spacing, while it completely disappears in the case of strong acidic conditions, demonstrating the complete filling of the clay interlayer. It is worth underlaying that, in the absence of surfactant functionalization [36], almost no change in the clay interlayer were detected at a low $\mathrm{pH}$. 


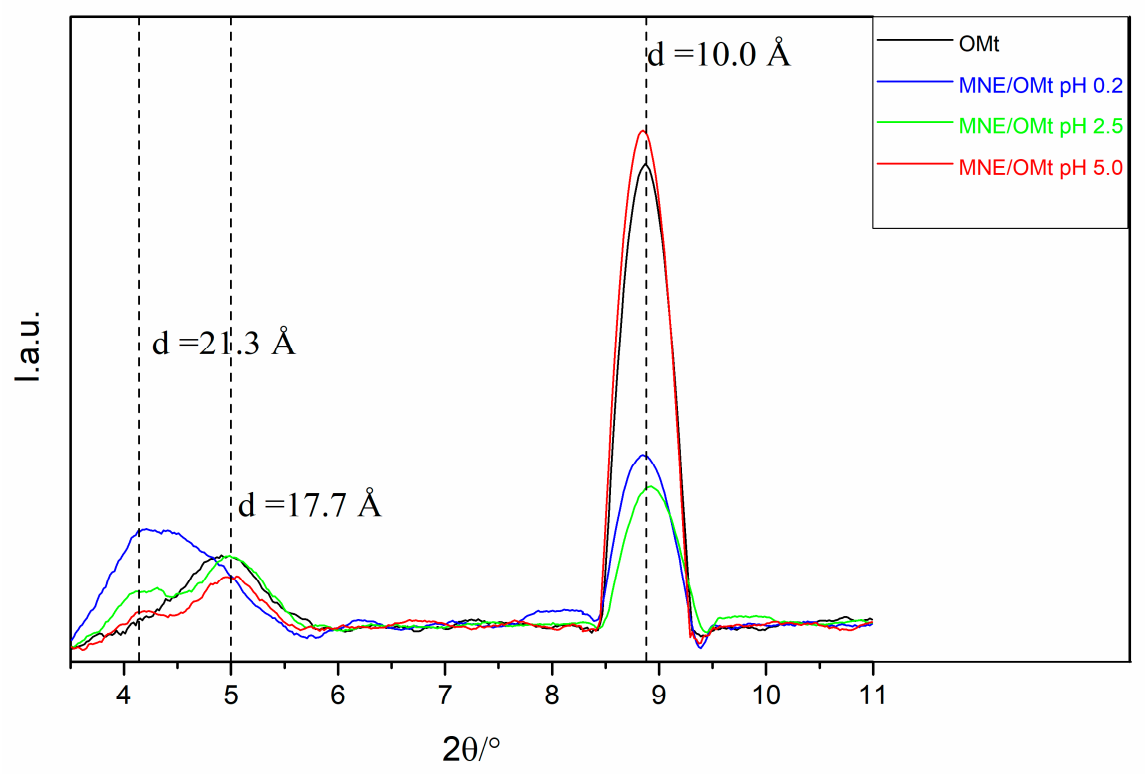

Figure 3. Superimposition of the smoothed XRD patterns in the low angle region for organomontmorillonite and metronidazole/organo-montmorillonite complexes prepared at different $\mathrm{pH}$ values.

\subsection{MNE Release Profiles from Organo-Clay Hybrids}

The in vitro release of metronidazole, from the MNE/OMt complexes, was studied by dialysis, using two different release media, the first at $\mathrm{pH} 1.0$ and the second at $\mathrm{pH} 6.8$ to mimic the gastric and intestinal fluids, respectively [67,68], thus reproducing the oral drug administration and physiological release.

Normalized UV-Vis spectra of the released drug were registered and compared with the MNE spectrum obtained at $\mathrm{pH} 6.8$ (Figure 4). The absence of significant changes both in the position and in the band shape clearly suggests that the kind of interaction between the organoclay and drug does not induce any change in the chemical nature of the an-tibiotic.

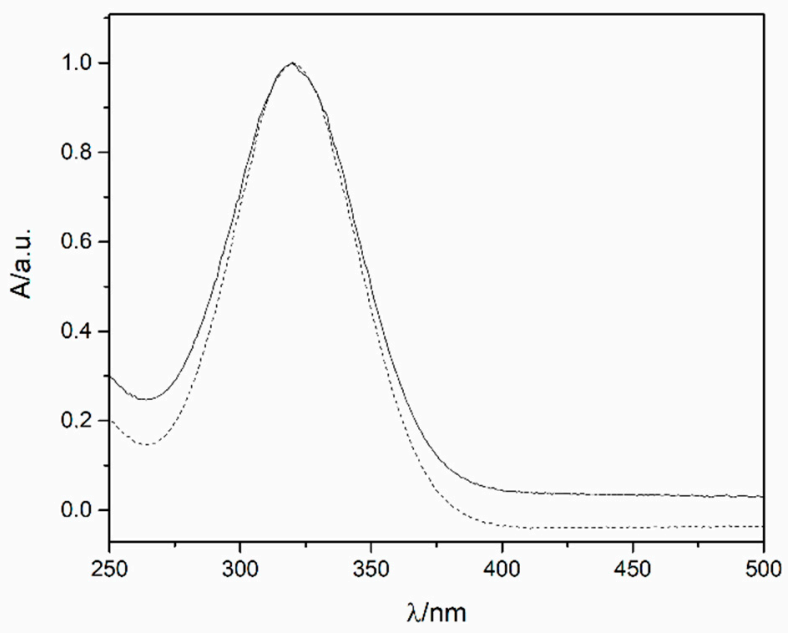

Figure 4. Typical normalized UV-VIS spectra of aqueous solution of metronidazole before (solid line) and after the release from organo-montmorillonite in the simulated intestinal fluids medium (dotted line).

Moreover, it is worth underlining that the retention time of the released drug remains unaltered, thus indicating no chemical modification of the antibiotic.

These are very important results that indicate that the drug activity is preserved, and the proposed formulation could be fruitfully exploited to successfully prolong the action of drug in the desired site. 
The release profiles of MNE from OMTs in SGF and SIF, obtained at $37.0^{\circ} \mathrm{C}$ under mechanical stirring conditions, are shown in Figure 5.

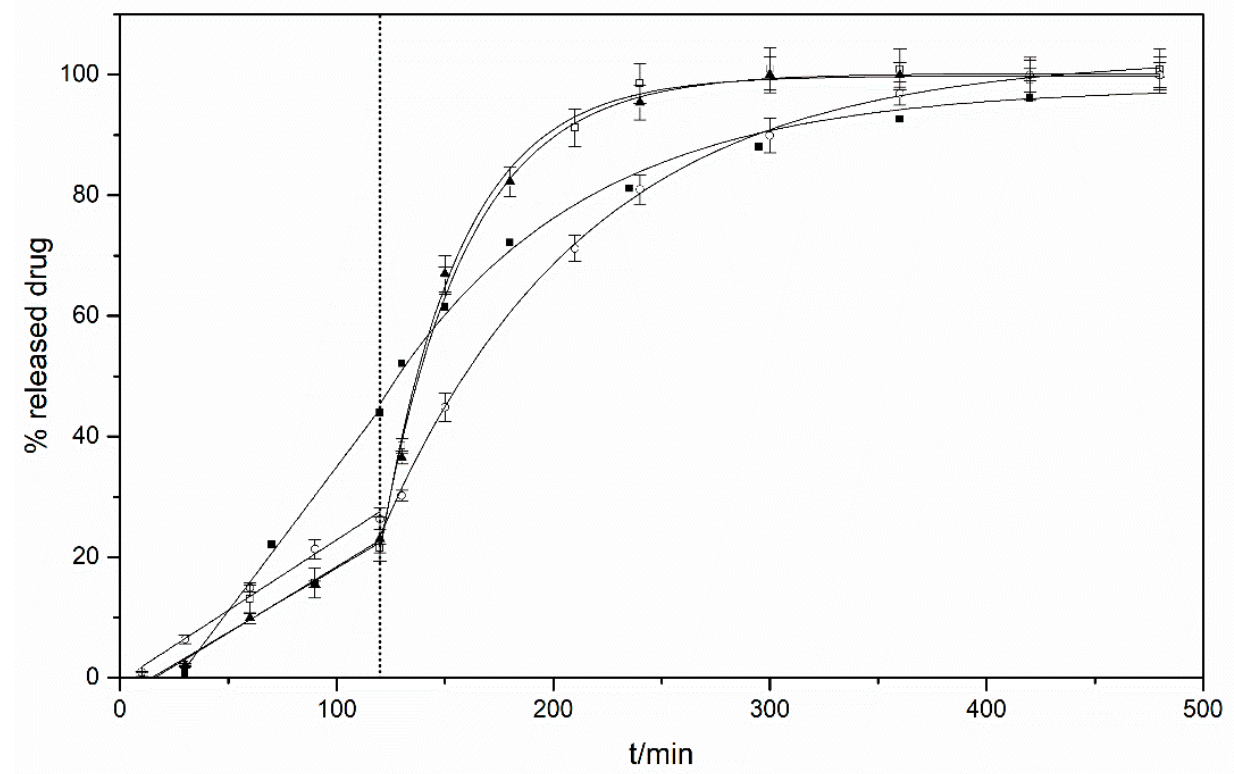

Figure 5. Kinetics of release of metronidazole from the organo-montmorillonites loaded with metronidazole at pH $0.2(\square), \mathrm{pH} 2.5(\mathbf{\Delta})$, and $\mathrm{pH} 5.0(\bigcirc)$ and from the commercial tablet $(\mathbf{\square})$ [55]. Line corresponds to the fit by the zero-order model (in the release medium at $\mathrm{pH}=1.0,0<t<120 \mathrm{~min}$ ) and by first-order model (release medium at $\mathrm{pH} 6.8,120<t<480 \mathrm{~min}$ ). Vertical bars represent the $\mathrm{SD}$, results are shown as mean \pm S.D.; $n=3$.

Results are reported in terms of percentage of the released drug (relative to the total amount of adsorbed drug) to make comparable results obtained for different OMTs with different antibiotic content.

The amount of drug released from the organoclays, for the first two hours at acidic $\mathrm{pH}$ (system mimicking the stomach), is about half of the amount released from the commercial tablet. On passing time $(6 \mathrm{~h})$ all the investigated systems release almost 100\% of drug in the buffered medium at $\mathrm{pH}=6.8$ (intestine).

In order to better understand the release mechanism, different kinetic models $[74,75]$ were tested and the choice of the model that better reproduces experimental data was performed based on the statistical criteria reported in Tables 3 and 4 .

Table 3. Selected figures of merit for the models applied to the experimental release kinetic profiles in SGF.

\begin{tabular}{ccccc}
\hline Kinetic Model & Figures of Merit & $\mathbf{p H ~ 0 . 2}$ & $\mathbf{p H ~ 2 . 5}$ & $\mathbf{p H ~ 5 . 0}$ \\
\hline Zero order & $\mathrm{R}^{2}$ & 0.98 & 0.99 & 0.99 \\
$Q_{t}=Q_{e}+k_{0} t$ & ESS & 18 & 17 & 4 \\
& ANOVA F value & 186 & 291 & 2500 \\
\hline \multirow{2}{*}{ First order } & $\mathrm{R}^{2}$ & 0.97 & 0.98 & 0.98 \\
$Q_{t}=Q_{e}\left(1-e^{-k_{1} t}\right)$ & $\chi^{2}$ & 5.3 & 1.1 & 0.8 \\
& ESS & 10.7 & 20.3 & 10 \\
& ANOVA F value & 54 & 254 & 1049 \\
Second order & $\mathrm{R}^{2}$ & 0.94 & 0.95 & 0.99 \\
$Q_{t}=Q_{e}\left(\frac{Q_{e} k_{2} t}{1+Q_{e} k_{2} t}\right)$ & $\chi^{2}$ & 6.2 & 5.9 & 1.5 \\
& ESS & 18.6 & 17.8 & 5.5 \\
& ANOVA F value & 69 & 72 & 462 \\
\hline
\end{tabular}

Note: $Q_{t}=$ amount of released drug at time $t, Q_{e}=$ amount of released drug at the equilibrium time, $k_{0}=$ zero-order kinetic rate constant, $k_{1}=$ first-order kinetic rate constant, $k_{2}=$ second-order kinetic rate constant, $A_{1}, A_{2}=$ preexponential factors related to two parallel reactions, $k^{\prime}, k^{\prime \prime}=$ kinetic rate constants related to two parallel reactions. 
Table 4. Selected figures of merit for the models applied to the experimental release kinetic profiles in SIF.

\begin{tabular}{ccccc}
\hline Kinetic Model & Figures of Merit & pH 0.2 & pH 2.5 & pH 5.0 \\
\hline First order & $\mathrm{R}^{2}$ & 0.99 & 0.99 & 0.99 \\
$Q_{t}=Q_{e}\left(1-e^{-k_{1} t}\right)$ & $\chi^{2}$ & 2.0 & 3.8 & 0.7 \\
& ESS & 12.3 & 22.98 & 3.6 \\
& ANOVA F value & 10,517 & 5410 & 23,700 \\
\hline Second order & $\mathrm{R}^{2}$ & 0.72 & 0.73 & 0.87 \\
$Q_{t}=Q_{e}\left(\frac{Q_{e} k_{2} t}{1+Q_{e} k_{2} t}\right)$ & $\chi^{2}$ & 296 & 256 & 88.9 \\
& ESS & 2078 & 1868 & 533 \\
& ANOVA F value & 105 & 112 & 289 \\
\hline \multirow{2}{*}{ Double exponential model } & $\mathrm{R}^{2}$ & 0.99 & 0.99 & 0.99 \\
$\left.Q_{t}=Q_{e}-A^{\prime} e^{-k^{\prime} t}-A / e^{-k / t}\right)$ & $\chi^{2}$ & 3.1 & 5.6 & 1.21 \\
& ESS & 12.1 & 22.6 & 365 \\
& ANOVA F value & 4213 & 2199 & 8536 \\
\hline
\end{tabular}

Note: $Q_{t}=$ amount of released drug at time $t, Q_{e}=$ amount of released drug at the equilibrium time, $k_{0}=$ zero-order kinetic rate constant, $k_{1}=$ first-order kinetic rate constant, $k_{2}=$ second-order kinetic rate constant, $A_{1}, A_{2}=$ preexponential factors related to two parallel reactions, $k^{\prime}, k^{\prime \prime}=$ kinetic rate constants related to two parallel reactions

It has been found that the model that better reproduces the release profiles in an acid environment is the zero-order model, which implies that the rate of desorption of the drug is independent of the amount of drug loaded on the organo-clay. As for the MNE release at $\mathrm{pH} 6.8$, it was found that it follows a first-order rate law, which implies that the drug is released proportionally to the amount of the drug bound to the clay mineral.

The kinetic rate constants $\left(k_{0}\right.$ and $\left.k_{1}\right)$, obtained from the fitting of the experimental data, are reported in Table 5 together with other characteristic parameters [75], i.e., the amount of drug released in a certain time, $t \%$, and the dissolution efficiency, $\mathrm{DE} \%$.

Table 5. Release parameters in the simulated gastric fluids (SGF) and simulated intestinal fluids (SIF) media.

\begin{tabular}{ccccccc}
\hline & \multicolumn{3}{c}{ Simulated Gastric Fluids } & \multicolumn{3}{c}{ Simulated Intestinal Fluids } \\
\cline { 2 - 7 } & $\boldsymbol{t}_{\mathbf{1 2 0}} \%$ & $\mathbf{D E} \%$ & $\boldsymbol{k}_{\mathbf{0}} / \mathbf{m i n}^{-\mathbf{1}}$ & $\boldsymbol{t}_{\mathbf{4 8 0} \%}$ & $\mathbf{D E \%}$ & $\boldsymbol{k}_{\mathbf{1}} / \mathbf{m i n}^{-\mathbf{1}}$ \\
\hline $\begin{array}{c}\text { Commercial } \\
\text { formulation }\end{array}$ & 44 & 18 & $0.48 \pm 0.03$ & 100 & 72 & $(1.1 \pm 0.1) \times 10^{-2}$ \\
\hline $\begin{array}{c}\text { MNE/OMt } \\
\text { pH 0.2 }\end{array}$ & 20 & 9.5 & $0.20 \pm 0.01$ & 100 & 87 & $(2.63 \pm 0.07) \times 10^{-2}$ \\
\hline $\begin{array}{c}\text { MNE/OMt } \\
\text { pH 2.5 }\end{array}$ & 24 & 10 & $0.21 \pm 0.01$ & 100 & 89,5 & $(2.6 \pm 0.1) \times 10^{-2}$ \\
\hline $\begin{array}{c}\text { MNE/OMt } \\
\text { pH 5.0 }\end{array}$ & 26 & 14 & $0.23 \pm 0.01$ & 100 & 75 & $(1.02 \pm 0.05) \times 10^{-2}$ \\
\hline
\end{tabular}

Note: $t_{120} \%=$ amount of drug released at time $=120 \mathrm{~min}, t_{480} \%=$ amount of drug released at time $=480 \mathrm{~min}$, $D E \%=$ dissolution efficiency $\left(D E \%=\frac{\int_{0}^{t} y d t}{y 100} t \cdot 100\right.$, where $y$ is the drug $\%$ dissolved at time $\left.t\right)$.

\subsection{Cell Viability Assay on Human Colon Cancer (HCT116) Cells}

The cytocompatibility of the constituents of the proposed formulations was investigated. Figure 6 reports data obtained incubating HCT116 cells with pure Tween 20 (Figure 6a) and with OMt (Figure 6b). Surfactant and clay concentrations correspond to the amounts contained in MNE/Mt and MNE/OMt hybrids. 

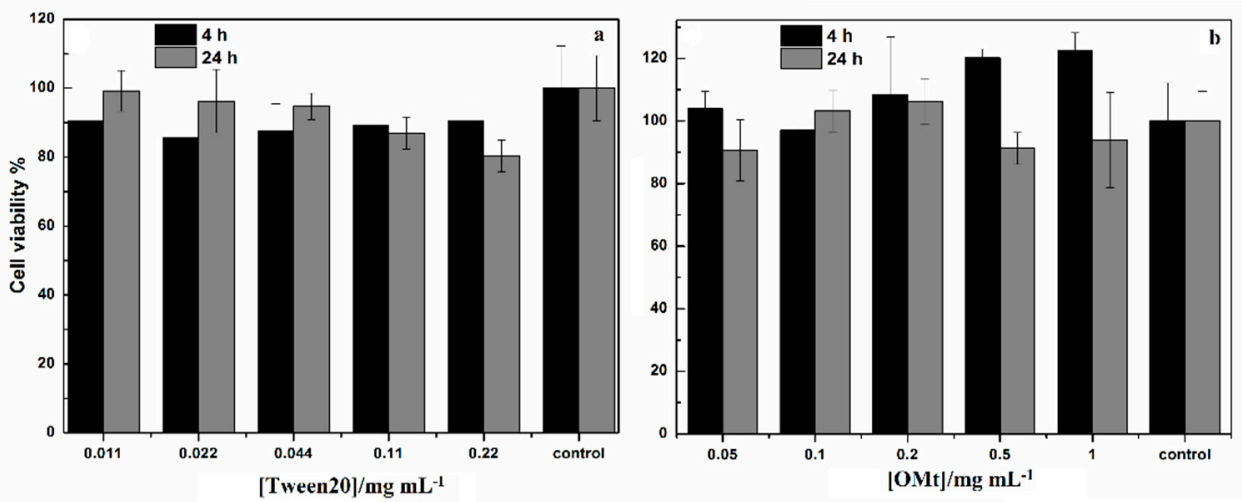

Figure 6. Effect of Tween20 (a) and organo-montmorillonite (b) on the cell viability of human colon cancer (HCT116) cells.

In Figure 7, the cytocompatibility profiles for free MNE, MNE/Mt, and MNE/OMt are reported.
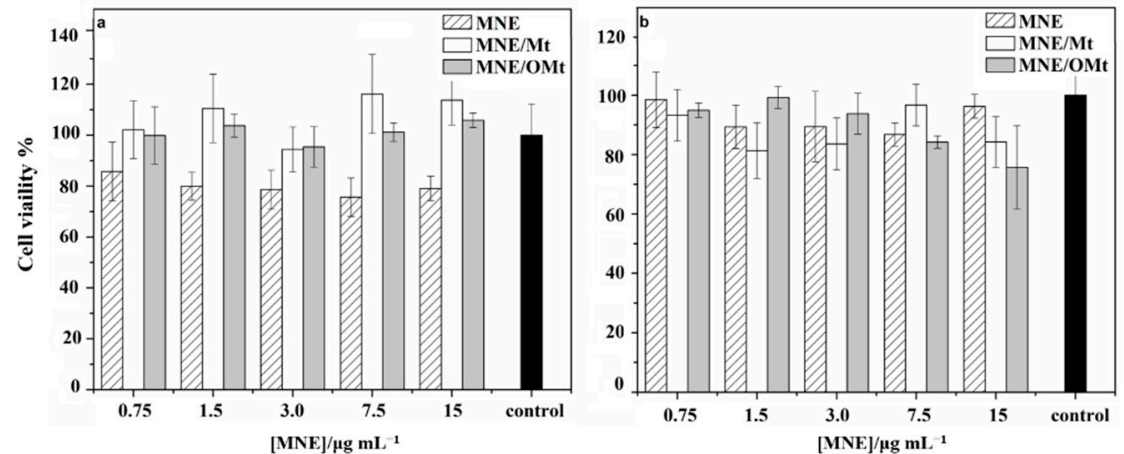

Figure 7. Effect of metronidazole, metronidazole/montmorillonite, and MNE/organo-montmorillonite complexes on the cell viability of human colon cancer (HCT116) cells at $4 \mathrm{~h}$ (a) and $24 \mathrm{~h}$ (b) of incubation.

\section{Discussion}

Results obtained from the construction of the adsorption isotherms (Figure 1) indicates that acidic conditions favor the drug uptake, due to the presence of $\mathrm{H}^{+}$ions promoting the intercalation of the drug in the interlayer region [76]. The same behavior was observed for drug uptake onto pristine montmorillonite [36].

Comparison with the adsorption isotherms of the same metronidazole onto the nonfunctionalized montmorillonite [36] showed that the presence of the surfactant leads to a decrease of the adsorbed amount. This could be ascribed to the steric hindrance effect of the Tween 20 in the clay interlayer and it could be taken as an indication that, regardless of the $\mathrm{pH}$ of preparation of the complexes, the adsorption occurs preferentially in the clay interlayer, rather than onto the lamella faces of the clay.

The occurrence of the Hill model indicates that the affinity of the drug toward the organoclay increases on increasing the amount of drug already adsorbed. Similar results were recently obtained in the case of the adsorption of cinnamic acid onto Tween20/montmorillonite hybrids [6] and for the cellular uptake of boronated porphyrin [76]

As for the n parameter, which is related to the cooperative process, it indicated that the cooperative effect is higher at a higher $\mathrm{pH}$.

Analysis of the XRD results, and in particular the behavior observed at strong acidic conditions, in comparison with the results of Calabrese et al. [36], evidence that the functionalization with the surfactant somehow drives the adsorption of the protonated form of the drug into the clay interlayer. 
This can be taken as an indication of the occurrence of cationic exchange processes in the clay interlayer involving the cationic form of the drug, while electrostatic interactions with the external lamella negative faces are hampered.

The small changes involving the adsorption process at higher $\mathrm{pH}$ values, in contrast with the behavior reported in [36] for the adsorption onto pristine clay, could be taken as an indication of the negligible adsorption of the neutral form of the drug predominating at $\mathrm{pH}=5.0$.

In the light of the obtained results, it was proposed that the adsorption of MNE onto OMt occurs preferentially in the clay interlayer through cationic exchange processes, while the electrostatic interactions onto the external surface and the intercalation of the neutral form of the drug through protonation reactions are prevented by the presence of the surfactant.

It can be concluded that strong acidic $\mathrm{pH}$ represents the optimal condition for the adsorption of MNE onto OMt since it promotes the complete intercalation of the drug and avoids adsorption onto other available sites in the clay.

Concerning the release profiles, the different behavior observed in the two physiological conditions may be ascribed to the different kind of exchangeable cations present in the media, i.e., $\mathrm{H}^{+}$in the stomach $\mathrm{pH}$ mimicking medium, and $\mathrm{Na}^{+}$and $\mathrm{K}^{+}$in the intestinal $\mathrm{pH}$ mimicking medium, and to the different affinity of the OMt toward the drug and the different cations that follow the order $\mathrm{H}^{+}<\mathrm{MNE}<\mathrm{Na}^{+} / \mathrm{K}^{+}$.

The low release of MNE from all systems at acid $\mathrm{pH}$, simulating the stomach environment, could allow for overcoming the undesirable side effects of MNE after oral administration, decreasing stomach damage and achieving sustained release of MTZ for efficient clinical use [77]. Worthy of note is that the complete release in the target point, i.e., the intestine, was not always reached in the case of the non-functionalized clay mineral [36].

The release profiles obtained in the case of other tailor-made drug delivery systems, reported in the literature [77-79] indicates comparable results in the SGF medium, but, again, the formulation proposed in the present work ensures a better release in the target point.

A perusal of data reported in Table 5 indicates that, in both SGF and SFI medium, the release rate of the drug does not depend on the $\mathrm{pH}$ of the sample preparation, except for the release from the hybrid prepared at $\mathrm{pH} 5$ which, in the SFI medium, is slightly slower, compared to the other organo-clays, which is due to the stronger interaction between the clay mineral and the neutral form of the drug. Analogously, the other release parameters are quite similar for the different hybrid complexes. This can be taken as a demonstration of the drug uptake onto the clay mineral interlayer, regardless of the $\mathrm{pH}$. Comparison with the data obtained from the investigation of the drug release from the non-functionalized clay mineral, allow us to assess that the surfactant drives the intercalation of the antibiotic into the interlamellar space.

The release profiles, common to all samples, allows us to consider the MNE/OMt complexes good candidates for the modified release of metronidazole in the context of the problem of intestinal amoebiasis. The MNE/OMt complexes satisfy the conditions for the local (intestinal) and not systemic treatment of infections caused by Entamoeba histolytica.

The other aspect to be considered to verify the efficacy of the proposed formulation, is the cytocompatibility. Concerning this point, negligible effect and no significant differences in cell viability were detected both after 4 and $24 \mathrm{~h}$, for all tested materials and range of concentration, with respect to the untreated control, indicating a good cytocompatibility of the constituents of the devices.

The data show that for all systems, cell viability is comparable to control. In more detail, cell viability is more than $80 \%$ even after 4 and $24 \mathrm{~h}$ of incubation under all experimental conditions. Moreover, although after $24 \mathrm{~h}$ (Figure $7 \mathrm{~b}$ ) the differences between free drug and nanodevices are not statistically significant, the viability of HCT116 cells incubated for $4 \mathrm{~h}$ (Figure 7a) with pure metronidazole is lower than the viability of HCT116 cells incubated with nanodevices. 
Cytotoxicity measurements allow one to assess the biocompatibility of the prepared complexes and evidenced that, under specific experimental conditions, nanodevices are more biocompatible than the free drug.

\section{Conclusions}

The main purpose of the present work was the exploitation of the peculiar features of tailor-made organoclays materials based on the non-ionic surfactant Tween20 and the Mt clay mineral, in the design of carrier systems for the administration of the metronidazole antibiotic. The work was aimed at improving the already valuable properties of montmorillonite/metronidazole nanodevices through the functionalization of the clay mineral with the surfactant to enhance the stability of the clay mineral dispersion and to better control drug adsorption and release.

The uptake process was investigated through systematic equilibrium studies and XRD characterization, which allows us to assess that the adsorption of MNE occurs preferentially in the clay mineral interlayer.

Drug release kinetics, performed under physiological $\mathrm{pH}$ conditions simulating the oral drug administration and delivery, showed excellent release profiles for the cure of intestinal amoebiasis, especially when compared with the commercial formulation. Moreover, the clay mineral functionalization with the non-ionic surfactant accomplishes the target objectives of i) improving the dispersion stability of the clay mineral, thus preventing flocculation and increasing the bioavailability of the drug, and ii) driving the adsorption of both the protonated and neutral form of the drug onto the clay mineral interlayer, thus allowing better control of the uptake and release of the drug.

Good biocompatibility of the prepared nanodevices completes the picture that makes them very promising for the preparation of effective antibiotic formulations.

Supplementary Materials: The following are available online at https:/ / www.mdpi.com/article/10 $.3390 / \min 11121315 / \mathrm{s} 1$, Figure S1: HPLC calibration curve.

Author Contributions: Conceptualization, L.S., G.C. and M.L.T.L.; investigation, L.S., I.C. and C.S.; writing and original draft preparation, L.S., G.C. and M.M.; review and editing, L.S., G.C. and M.M.; supervision, L.S., G.C. and M.M.; resources and funding acquisition, G.C., M.M. and M.L.T.L. All authors have read and agreed to the published version of the manuscript.

Funding: This research was funded by the University of Palermo (FFR 2012-2013, FFR 2018-20121).

Conflicts of Interest: The authors declare no conflict of interest.

\section{References}

1. Nikolaidis, A.K.; Koulaouzidou, E.A.; Achilias, D.S. Synthesis and Characterization of Novel Organomodified Nanoclays for Application in Dental Materials. Curr. Nanosci. 2019, 15, 512-524. [CrossRef]

2. Cavallaro, G.; Lazzara, G.; Milioto, S.; Parisi, F.; Sciascia, L. Clay/Non-Ionic Surfactant Hybrid Nanocomposites. In Functionalized Nanomaterials I; Kumar, V., Guleria, P., Dasgupta, N., Ranjan, S., Eds.; CRC Press: Boca Raton, FL, USA, 2020; pp. 269-278, ISBN 9781351021623.

3. Lobato-Aguilar, H.; Uribe-Calderón, J.A.; Herrera-Kao, W.; Duarte-Aranda, S.; Baas-López, J.M.; Escobar-Morales, B.; CauichRodríguez, J.V.; Cervantes-Uc, J.M. Synthesis, Characterization and Chlorhexidine Release from Either Montmorillonite or Palygorskite Modified Organoclays for Antibacterial Applications. J. Drug Deliv. Sci. Technol. 2018, 46, 452-460. [CrossRef]

4. De Oliveira, T.; Guégan, R.; Thiebault, T.; Milbeau, C.L.; Muller, F.; Teixeira, V.; Giovanela, M.; Boussafir, M. Adsorption of Diclofenac onto Organoclays: Effects of Surfactant and Environmental (PH and Temperature) Conditions. J. Hazard. Mater. 2017, 323, 558-566. [CrossRef] [PubMed]

5. Ruiz-Hitzky, E.; Aranda, P.; Darder, M.; Rytwo, G. Hybrid Materials Based on Clays for Environmental and Biomedical Applications. J. Mater. Chem. 2010, 20, 9306. [CrossRef]

6. Calabrese, I.; Gelardi, G.; Merli, M.; Liveri, M.L.T.; Sciascia, L. Clay-Biosurfactant Materials as Functional Drug Delivery Systems: Slowing down Effect in the In Vitro Release of Cinnamic Acid. Appl. Clay Sci. 2017, 135, 567-574. [CrossRef]

7. Yan, H.; Chen, X.; Bao, C.; Yi, J.; Lei, M.; Ke, C.; Zhang, W.; Lin, Q. Synthesis and Assessment of CTAB and NPE Modified OrganoMontmorillonite for the Fabrication of Organo-Montmorillonite/Alginate Based Hydrophobic Pharmaceutical Controlled-Release Formulation. Colloids Surf. B Biointerfaces 2020, 191, 110983. [CrossRef] 
8. Choy, J.; Choi, S.; Oh, J.; Park, T. Clay Minerals and Layered Double Hydroxides for Novel Biological Applications. Appl. Clay Sci. 2007, 36, 122-132. [CrossRef]

9. De Sousa Rodrigues, L.A.; Figueiras, A.; Veiga, F.; de Freitas, R.M.; Nunes, L.C.C.; da Silva Filho, E.C.; da Silva Leite, C.M. The Systems Containing Clays and Clay Minerals from Modified Drug Release: A Review. Colloids Surf. B Biointerfaces 2013, 103, 642-651. [CrossRef]

10. Hun Kim, M.; Choi, G.; Elzatahry, A.; Vinu, A.; Bin Choy, Y.; Choy, J.-H. Review of Clay-Drug Hybrid Materials for Biomedical Applications: Administration Routes. Clays Clay Miner. 2016, 64, 115-130. [CrossRef] [PubMed]

11. Carazo, E.; Borrego-Sánchez, A.; Sánchez-Espejo, R.; García-Villén, F.; Cerezo, P.; Aguzzi, C.; Viseras, C. Kinetic and Thermodynamic Assessment on Isoniazid/Montmorillonite Adsorption. Appl. Clay Sci. 2018, 165, 82-90. [CrossRef]

12. Massaro, M.; Colletti, C.G.; Lazzara, G.; Riela, S. The Use of Some Clay Minerals as Natural Resources for Drug Carrier Applications. J. Funct. Biomater. 2018, 9, 58. [CrossRef]

13. Cavalcanti, G.R.S.; Fonseca, M.G.; da Silva Filho, E.C.; Jaber, M. Thiabendazole/Bentonites Hybrids as Controlled Release Systems. Colloids Surf. B Biointerfaces 2019, 176, 249-255. [CrossRef]

14. García-Villén, F.; Faccendini, A.; Aguzzi, C.; Cerezo, P.; Bonferoni, M.C.; Rossi, S.; Grisoli, P.; Ruggeri, M.; Ferrari, F.; Sandri, G.; et al. Montmorillonite-Norfloxacin Nanocomposite Intended for Healing of Infected Wounds. Int. J. Nanomed. 2019, 14, 5051-5060. [CrossRef]

15. Peña-Parás, L.; Sánchez-Fernández, J.A.; Vidaltamayo, R. Nanoclays for Biomedical Applications. In Handbook of Ecomaterials; Martínez, L.M.T., Kharissova, O.V., Kharisov, B.I., Eds.; Springer International Publishing: Cham, Switzerland, 2019; pp. 3453-3471, ISBN 9783319682556.

16. De Melo Barbosa, R.; Alcântara, M.; Meirelles, L.; Zorato, N.; Raffin, F. Nanoclays in drug delivery systems. In Clay Nanoparticles; Elsevier: Amsterdam, The Netherlands, 2020; pp. 185-202, ISBN 9780128167830.

17. García-Villén, F.; Viseras, C. Clay-Based Pharmaceutical Formulations and Drug Delivery Systems. Pharmaceutics 2020, $12,1142$. [CrossRef]

18. Khatoon, N.; Chu, M.Q.; Zhou, C.H. Nanoclay-Based Drug Delivery Systems and Their Therapeutic Potentials. J. Mater. Chem. B 2020, 8, 7335-7351. [CrossRef]

19. Martín, S.A.; Pérez, I.; Rivera, A. Hosting of the Antibiotic Vancomycin by Bentonite: Characterization and Slow Release Study. Appl. Clay Sci. 2021, 202, 105965. [CrossRef]

20. Aguzzi, C.; Cerezo, P.; Viseras, C.; Caramella, C. Use of Clays as Drug Delivery Systems: Possibilities and Limitations. Appl. Clay Sci. 2007, 36, 22-36. [CrossRef]

21. Calabrese, I.; Cavallaro, G.; Lazzara, G.; Merli, M.; Sciascia, L.; Liveri, M.L.T. Preparation and Characterization of Bio-Organoclays Using Nonionic Surfactant. Adsorption 2016, 22, 105-116. [CrossRef]

22. Gu, Z.; Gao, M.; Lu, L.; Liu, Y.; Yang, S. Montmorillonite Functionalized with Zwitterionic Surfactant as a Highly Efficient Adsorbent for Herbicides. Ind. Eng. Chem. Res. 2015, 54, 4947-4955. [CrossRef]

23. Lazorenko, G.; Kasprzhitskii, A.; Yavna, V. Comparative Study of the Hydrophobicity of Organo-Montmorillonite Modified with Cationic, Amphoteric and Nonionic Surfactants. Minerals 2020, 10, 732. [CrossRef]

24. Lee, S.Y.; Kim, S.J. Delamination Behavior of Silicate Layers by Adsorption of Cationic Surfactants. J. Colloid Interface Sci. 2002, 248, 231-238. [CrossRef]

25. Martos, R.; Guggenheim, S.; Sainz-Díaz, C. Interlayer Water Molecules in Organocation-Exchanged Vermiculite and Montmorillonite: A Case Study of Tetramethylammonium. Am. Mineral. 2013, 98, 1535. [CrossRef]

26. Sciascia, L.; Casella, S.; Cavallaro, G.; Lazzara, G.; Milioto, S.; Princivalle, F.; Parisi, F. Olive Mill Wastewaters Decontamination Based on Organo-Nano-Clay Composites. Thermophys. Asp. Funct. Ceram. Surf. 2019, 45, 2751-2759. [CrossRef]

27. Dening, T.J.; Rao, S.; Thomas, N.; Prestidge, C.A. Montmorillonite-Lipid Hybrid Carriers for Ionizable and Neutral Poorly Water-Soluble Drugs: Formulation, Characterization and In Vitro Lipolysis Studies. Int. J. Pharm. 2017, 526, 95-105. [CrossRef] [PubMed]

28. Jayrajsinh, S.; Shankar, G.; Agrawal, Y.K.; Bakre, L. Montmorillonite Nanoclay as a Multifaceted Drug-Delivery Carrier: A Review. J. Drug Deliv. Sci. Technol. 2017, 39, 200-209. [CrossRef]

29. Nielsen, R.B.; Kahnt, A.; Dillen, L.; Wuyts, K.; Snoeys, J.; Nielsen, U.G.; Holm, R.; Nielsen, C.U. Montmorillonite-Surfactant Hybrid Particles for Modulating Intestinal P-Glycoprotein-Mediated Transport. Int. J. Pharm. 2019, 571, 118696. [CrossRef] [PubMed]

30. Borrego-Sánchez, A.; Sánchez-Espejo, R.; García-Villén, F.; Viseras, C.; Sainz-Díaz, C.I. Praziquantel-Clays as Accelerated Release Systems to Enhance the Low Solubility of the Drug. Pharmaceutics 2020, 12, 914. [CrossRef]

31. Lobato-Aguilar, H.A.; Lizama-Uc, G.; Uribe-Calderon, J.A.; Cauich-Rodriguez, J.; Rodriguez-Fuentes, N.; Cervantes-Uc, J.M. Antibacterial Properties and Release Kinetics of Chlorhexidine Diacetate from Montmorillonite and Palygorskite Clays. J. Biomater. Appl. 2020, 34, 1052-1058. [CrossRef] [PubMed]

32. Sabzevari, A.G.; Sabahi, H.; Nikbakht, M. Montmorillonite, a Natural Biocompatible Nanosheet with Intrinsic Antitumor Activity. Colloids Surf. B Biointerfaces 2020, 190, 110884. [CrossRef]

33. Kumar, A.; Ramisetty, K.A.; Bordignon, S.; Hodnett, B.K.; Davern, P.; Hudson, S. Preparation, Stabilisation, Isolation and Tableting of Valsartan Nanoparticles Using a Semi-Continuous Carrier Particle Mediated Process. Int. J. Pharm. 2021, $597,120199$. [CrossRef] 
34. Sreekanth Reddy, O.; Subha, M.C.S.; Jithendra, T.; Madhavi, C.; Chowdoji Rao, K. Curcumin Encapsulated Dual Cross Linked Sodium Alginate/Montmorillonite Polymeric Composite Beads for Controlled Drug Delivery. J. Pharm. Anal. 2021, 11, 191-199. [CrossRef]

35. Hazen, R.M.; Sverjensky, D.A.; Azzolini, D.; Bish, D.L.; Elmore, S.C.; Hinnov, L.; Milliken, R.E. Clay Mineral Evolution. Am. Mineral. 2013, 98, 2007-2029. [CrossRef]

36. Calabrese, I.; Cavallaro, G.; Scialabba, C.; Licciardi, M.; Merli, M.; Sciascia, L.; Liveri, M.L.T. Montmorillonite Nanodevices for the Colon Metronidazole Delivery. Spec. Sect. Formul. Better Med. Child. 2013, 457, 224-236. [CrossRef] [PubMed]

37. Goodman, L.S.; Brunton, L.L.; Gilman, A.; Chabner, B.; Knollmann, B.C.; Goodman, L.S. Goodman E Gilman's The Pharmacological Basis of Therapeutics; McGraw-Hill Medical: New York, NY, USA, 2011; ISBN 9780071593236.

38. Samuelson, J. Why Metronidazole Is Active against Both Bacteria and Parasites. Antimicrob. Agents Chemother. 1999, 43, 1533-1541. [CrossRef] [PubMed]

39. Amidon, S.; Brown, J.E.; Dave, V.S. Colon-Targeted Oral Drug Delivery Systems: Design Trends and Approaches. AAPS PharmSciTech 2015, 16, 731-741. [CrossRef]

40. Awasthi, R.; Kumar, M. Development of Metronidazole-Loaded Colon-Targeted Microparticulate Drug Delivery System. Polym. Med. 2015, 45, 57-65. [CrossRef]

41. Holešová, S.; Hundáková, M.; Tarasiuk, Y.; Čech Barabaszová, K.; Pazdziora, E. Metronidazole/Clay Nanocomposites: Synthesis, Structure and Antibacterial Efficacy. Mater. Today Proc. 2021, 37, 21-27. [CrossRef]

42. Latha, S.; Selvamani, P.; Kumar, C.S.; Sharavanan, P.; Suganya, G.; Beniwal, V.S.; Rao, P.R. Formulation Development and Evaluation of Metronidazole Magnetic Nanosuspension as a Magnetic-Targeted and Polymeric-Controlled Drug Delivery System. J. Magn. Magn. Mater. 2009, 321, 1580-1585. [CrossRef]

43. Li, J.; Hao, X.; Wang, C.; Liu, H.; Liu, L.; He, X.; Sun, C.C. Improving the Solubility, Dissolution, and Bioavailability of Metronidazole via Cocrystallization with Ethyl Gallate. Pharmaceutics 2021, 13, 546. [CrossRef]

44. Preisig, D.; Varum, F.; Bravo, R.; Hartig, C.; Spleiss, J.; Abbes, S.; Caobelli, F.; Wild, D.; Puchkov, M.; Huwyler, J.; et al. Colonic Delivery of Metronidazole-Loaded Capsules for Local Treatment of Bacterial Infections: A Clinical Pharmacoscintigraphy Study. Eur. J. Pharm. Biopharm. 2021, 165, 22-30. [CrossRef]

45. Ali, A.; Kaldhone, P.; Shirode, A.; Kadam, V. Report on Pharmaceutical Approaches to Colon Targeted Drug Delivery Systems. J. Pharm. Res. 2010, 3, 470-473.

46. Herculano, R.D.; Alencar de Queiroz, A.A.; Kinoshita, A.; Oliveira, O.N.; Graeff, C.F.O. On the Release of Metronidazole from Natural Rubber Latex Membranes. Mater. Sci. Eng. C 2011, 31, 272-275. [CrossRef]

47. Krishnaiah, Y.S.R.; Bhaskar Reddy, P.R.; Satyanarayana, V.; Karthikeyan, R.S. Studies on the Development of Oral Colon Targeted Drug Delivery Systems for Metronidazole in the Treatment of Amoebiasis. Int. J. Pharm. 2002, 236, 43-55. [CrossRef]

48. Al Jalali, V.; Zeitlinger, M. Systemic and Target-Site Pharmacokinetics of Antiparasitic Agents. Clin. Pharmacokinet. 2020, 59, 827-847. [CrossRef] [PubMed]

49. Burnhill, G.; Starkey, E. What Do I Need to Know about Metronidazole? Arch. Dis. Child. Educ. Pract. Ed. 2018, 103, 307-309. [CrossRef]

50. Goolsby, T.A.; Jakeman, B.; Gaynes, R.P. Clinical Relevance of Metronidazole and Peripheral Neuropathy: A Systematic Review of the Literature. Int. J. Antimicrob. Agents 2018, 51, 319-325. [CrossRef] [PubMed]

51. Hernández Ceruelos, A.; Romero-Quezada, L.C.; Ruvalcaba Ledezma, J.C.; López Contreras, L. Therapeutic Uses of Metronidazole and Its Side Effects: An Update. Eur. Rev. Med. Pharmacol. Sci. 2019, 23, 397-401. [CrossRef]

52. Lamp, K.C.; Freeman, C.D.; Klutman, N.E.; Lacy, M.K. Pharmacokinetics and Pharmacodynamics of the Nitroimidazole Antimicrobials. Clin. Pharmacokinet. 1999, 36, 353-373. [CrossRef] [PubMed]

53. Lau, A.H.; Lam, N.P.; Piscitelli, S.C.; Wilkes, L.; Danziger, L.H. Clinical Pharmacokinetics of Metronidazole and Other Nitroimidazole Anti-Infectives. Clin. Pharmacokinet. 1992, 23, 328-364. [CrossRef]

54. Calabrese, I.; Gelardi, G.; Merli, M.; Rytwo, G.; Sciascia, L.; Liveri, M.L.T. New Tailor-Made Bio-Organoclays for the Remediation of Olive Mill Waste Water. IOP Conf. Ser. Mater. Sci. Eng. 2013, 47, 012040. [CrossRef]

55. Galamboš, M.; Paučová, V.; Kufčáková, J.; Rosskopfová, O.; Rajec, P.; Adamcová, R. Cesium Sorption on Bentonites and Mont morillonite K10. J. Radioanal. Nucl. Chem. 2010, 284, 55-64. [CrossRef]

56. Golubeva, O.Y.; Pavlova, S.V.; Yakovlev, A.V. Adsorption and In Vitro Release of Vitamin B1 by Synthetic Nanoclays with Montmorillonite Structure. Appl. Clay Sci. 2015, 112-113, 10-16. [CrossRef]

57. Leite, S.T.; do Nascimento, F.H.; Masini, J.C. Fe(III)-Polyhydroxy Cations Supported onto K10 Montmorillonite for Removal of Phosphate from Waters. Heliyon 2020, 6, e03868. [CrossRef]

58. Madurai, S.L.; Joseph, S.W.; Mandal, A.B.; Tsibouklis, J.; Reddy, B.S.R. Intestine-Specific, Oral Delivery of Captopril/Montmorillonite: Formulation and Release Kinetics. Nanoscale Res. Lett. 2011, 6, 1-8. [CrossRef] [PubMed]

59. Parisi, F. Adsorption and Separation of Crystal Violet, Cerium(III) and Lead(II) by Means of a Multi-Step Strategy Based on K10-Montmorillonite. Minerals 2020, 10, 466. [CrossRef]

60. Parisi, F.; Lazzara, G.; Merli, M.; Milioto, S.; Princivalle, F.; Sciascia, L. Simultaneous Removal and Recovery of Metal Ions and Dyes from Wastewater through Montmorillonite Clay Mineral. Nanomaterials 2019, 9, 1699. [CrossRef] [PubMed]

61. Popugaeva, D.; Manoli, K.; Kreyman, K.; Ray, A.K. Removal of Aluminum from Aqueous Solution by Adsorption on Montmorillonite $\mathrm{K}_{10}, \mathrm{TiO}_{2}$, and $\mathrm{SiO}_{2}$ : Kinetics, Isotherms, and Effect of Ions. Adsorption 2019, 25, 1575-1583. [CrossRef] 
62. Sarma, G.; Sengupta, S.; Bhattacharyya, K. Montmorillonite $\mathrm{K}_{10}$ : An Effective Adsorbent for Removal of a Toxic Reactive Mono-Azo Dye, Procion Red MX 5B, from Water. J. Surf. Sci. Technol. 2014, 30, 163-178.

63. Alekseeva, O.; Noskov, A.; Grishina, E.; Ramenskaya, L.; Kudryakova, N.; Ivanov, V.; Agafonov, A. Structural and Thermal Properties of Montmorillonite/Ionic Liquid Composites. Materials 2019, 12, 2578. [CrossRef] [PubMed]

64. Mucha, M.; Maršálek, R.; Bukáčková, M.; Zelenková, G. Interaction among Clays and Bovine Serum Albumin. RSC Adv. 2020, 10, 43927-43939. [CrossRef]

65. Cavallaro, G.; Lazzara, G.; Milioto, S. Dispersions of Nanoclays of Different Shapes into Aqueous and Solid Biopolymeric Matrices. Extended Physicochemical Study. Langmuir 2011, 27, 1158-1167. [CrossRef] [PubMed]

66. Gibson, R.A.; Lattanzio, L.; McGee, H. Optimized Liquid-Chromatographic Determination of Metronidazole and Its Metabolites in Plasma. Clin. Chem. 1984, 30, 784. [CrossRef]

67. Ognibene, M.C.; Rocco, F.; Craparo, E.F.; Picone, P.; Ceruti, M.; Giammona, G. Biocompatible Micelles Based on Squalene Portions Linked to PEGylated Polyaspartamide as Potential Colloidal Drug Carriers. Curr. Nanosci. 2011, 7, 747-756. [CrossRef]

68. Tripodo, G.; Pitarresi, G.; Palumbo, F.; Craparo, E.; Giammona, G. UV-Photocrosslinking of Inulin Derivatives to Produce Hydrogels for Drug Delivery Application. Macromol. Biosci. 2005, 5, 1074-1084. [CrossRef]

69. Bagchi, B.; Dey, S.; Bhandary, S.; Das, S.; Bhattacharya, A.; Basu, R.; Nandy, P. Antimicrobial Efficacy and Biocompatibility Study of Copper Nanoparticle Adsorbed Mullite Aggregates. Mater. Sci. Eng. C 2012, 32, 1897-1905. [CrossRef]

70. Samstein, R.M.; Perica, K.; Balderrama, F.; Look, M.; Fahmy, T.M. The Use of Deoxycholic Acid to Enhance the Oral Bioavailability of Biodegradable Nanoparticles. Biomaterials 2008, 29, 703-708. [CrossRef]

71. Merli, M.; Sciascia, L.; Turco Liveri, M.L. Regression Diagnostics Applied in Kinetic Data Processing: Outlier Recognition and Robust Weighting Procedures. Int. J. Chem. Kinet. 2010, 42, 587-607. [CrossRef]

72. Ringot, D.; Lerzy, B.; Chaplain, K.; Bonhoure, J.-P.; Auclair, E.; Larondelle, Y. In Vitro Biosorption of Ochratoxin A on the Yeast Industry By-Products: Comparison of Isotherm Models. Bioresour. Technol. 2007, 98, 1812-1821. [CrossRef] [PubMed]

73. Marsh, A.; Heath, A.; Patureau, P.; Evernden, M.; Walker, P. Alkali Activation Behaviour of Un-Calcined Montmorillonite and Illite Clay Minerals. Appl. Clay Sci. 2018, 166, 250-261. [CrossRef]

74. Sciascia, L.; Turco Liveri, M.L.; Merli, M. Kinetic and Equilibrium Studies for the Adsorption of Acid Nucleic Bases onto K10 Montmorillonite. Appl. Clay Sci. 2011, 53, 657-668. [CrossRef]

75. Costa, P.; Lobo, S.; José, M. Modeling and Comparison of Dissolution Profiles. Eur. J. Pharm. Sci. 2001, 13, 123-133. [CrossRef]

76. Novick, S.; Laster, B.; Quastel, M.R. Positive Cooperativity in the Cellular Uptake of a Boronated Porphyrin. Int. J. Biochem. Cell Biol. 2006, 38, 1374-1381. [CrossRef]

77. Chen, T.; Chen, L.; Li, H.; Chen, Y.; Guo, H.; Shu, Y.; Chen, Z.; Cai, C.; Guo, L.; Zhang, X.; et al. Design and In Vitro Evaluation of a Novel Poly(Methacrylic Acid)/Metronidazole Antibacterial Nanogel as an Oral Dosage Form. Colloids Surf. B Biointerfaces 2014, 118, 65-71. [CrossRef] [PubMed]

78. Marcelo, G.; Ferreira, I.C.; Viveiros, R.; Casimiro, T. Development of itaconic acid-based molecular imprinted polymers using supercritical fluid technology for pH-triggered drug delivery. Int. J. Pharm. 2018, 542, 125-131. [CrossRef] [PubMed]

79. Wang, Z.; Li, B.; Ma, P.; Yang, W.; Liu, M.; Huang, Q.; Wei, S. Preparation and in vitro evaluation of macrocyclic metronidazole conjugates as an oral colon-specific delivery system. J. Incl. Phenom. Macrocycl. Chem. 2014, 78, 501-504. [CrossRef] 